\title{
Hyping results 'could damage' gene therapy
}

Washington. US biomedical researchers and their sponsors have been criticized for "overselling" the result of somatic gene therapy trials by a leading advisory panel to the National Institutes of Health (NIH), which has called for greater emphasis to be given to more basic, rather than clinical, research in the field.

The conclusions have come as little surprise to researchers involved in this work, partly because of their earlier release in draft form, and partly because they coincide with the views of Harold Varmus, the director of NIH, who set up the ad hoc panel to assess the NIH's investment in this rapidly expanding field.

But the panel's views are still likely to have considerable influence on future patterns of NIH research funding. Varmus will soon set up a new panel, provisionally called the NIH Gene Therapy Coordinating Group and including the directors of several NIH institutes, to study how to implement the panel's recommendations.

Up to 4 December, the NIH's Recombinant DNA Advisory Committee had approved 136 clinical protocols involving gene transfer, while 910 subjects had undergone NIH-supported gene transfer trials in the United States, and 1,024 had undergone trials worldwide. The report, presented to a meeting of the NIH director's advisory committee last week, acknowledges that gene therapy offers "extraordinary" long-term potential for managing and curing many diseases.

At the same time, however, the panel warns that a rush of prematurely optimistic publicity risks eroding public confidence and damaging the field. Investigators and their supporters, it concludes, should therefore be "more restrained" in public discussion of their findings and the prospects for genebased therapies. "There was a uniform feeling that there has been an overselling of current research in the field, which has led to an inaccurate perception of success," says Stuart Orkin of Harvard Medical School, who co-chaired the panel.

According to the panel, excessively optimistic public perceptions may in turn be causing patients to make poor therapeutic and reproductive decisions, in the belief that cures are imminent. Indeed, it says that, despite anecdotal claims to the contrary, clinical efficacy has not been definitively demonstrated in any gene therapy protocol.

Reflecting this conclusion, the report calls for increased emphasis on basic research. "In the enthusiasm to begin human gene therapy trials soon after gene discovery, important aspects of disease pathophysiology, cell biology and biochemistry have often been under-emphasized," it says.

In particular, the panel calls for more research on gene transfer and expression. It recommends "vigorous" and expanded research to improve vectors for gene delivery. The panel urges greater focus on maintaining high-level expression of transferred genes, directing gene transfer to specific cell types, and an understanding of how recipient cells handle and express foreign DNA.

The report also urges strict adherence to high standards in clinical protocols. "Inherent in that [proposal] is the suggestion that we don't think that's been the case so far," says Orkin. "Some [clinical studies] need to be done. But they must be informative and of high quality," he said after the meeting..

The committee complains that the poor design of clinical studies often means that

\section{Funds are key to sequence success}

Washington. Francis S. Collins, director of the US National Center for Human Genome Research, predicted last week that, "barring a disaster in funding", 99 per cent of the human genome sequence will be completed at an accuracy of 99.9 per cent by the year 2002 or 2003, considerably earlier than the initial target date of 2005.

At the same time, he expressed both concern and frustration about a continuing dispute over the NIH budget. Collins pointed out that, more than two months into the current fiscal year, he still does not know the size of the project's budget for the year. As a result, his office is reviewing proposals for large-scale sequencing work "not knowing if we have any money to spend".

Collins was speaking at a symposium held to mark the fifth anniversary of the Human Genome Project. He pointed out that, for a number of goals set in 1990, "we are either ahead of schedule, under budget, or both". For example, linkage maps due to become available at the end of 1995 were published in mid-1993, and high-accuracy physical gene maps are now expected to be available in 1998.

He confirmed his view that the time is ripe to "shift full tilt into sequencing" from mapping. In three years, Collins predicted, every genome centre funded by his office will be doing sequencing, compared to the handful now doing so.

Yet even though there is both bipartisan support in Congress and enthusiasm in the administration for human genome research, funding prospects remain uncertain. "When people are in a position of trying to make cuts wherever possible, and deals are being made late at night behind closed doors, you never know how it's going to settle," Collins said.
Patrick Young they do not yield any useful information when they fail - for example, when no detectable gene transfer occurs. But it nevertheless stresses that there exists a "clear and legitimate" need for clinical studies, partly because trials with animals cannot always be extrapolated to humans.

The 14-member panel, which had been asked to carry out a broad review of gene therapy research and develop recommendations on NIH-sponsored research, spent seven months preparing its report. Varmus

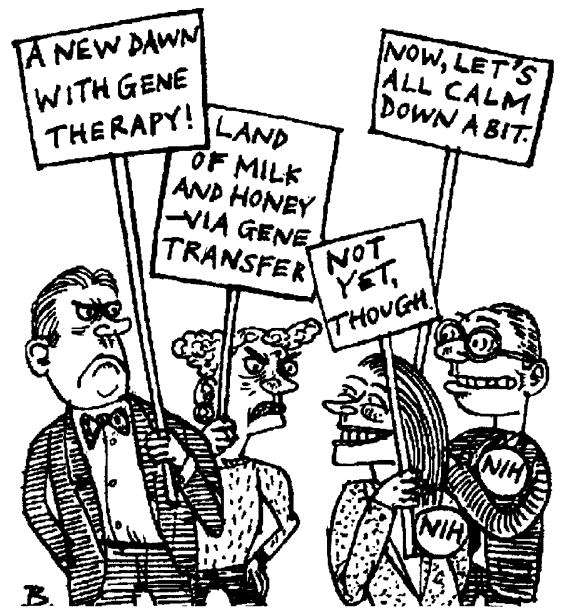

described last week it as "exceptionally good," and said that he agreed with its warning about publicity. Without evidence of the efficacy of gene therapy, he said, "an extrapolation from hope to hype is really not appropriate".

But the conclusions have already come under fire from some practising clinicians. Malcolm Brenner, for example, director of the cell and gene therapy programme at $\mathrm{St}$ Jude's Children's Research Hospital in Memphis, Tennessee, describes its conclusions as "obvious", pointing out that the committee was "largely devoid of people practising clinical gene therapy".

As a result, Varmus "got the answer that he wanted" says Brenner, who claims that there is no "absurd bias" toward clinical research in gene therapy.

Nevertheless the report appears to vindicate the NIH's current strategy. In the financial year that ended in September, the institutes spent $\$ 181.5$ million of their $\$ 11.3$ billion budget on gene therapy, with about $\$ 50$ million going to basic research and the rest to clinical and applied research. It expects to spend \$194 million in the current financial year.

The panel described these spending levels as "appropriate". It did not recommend establishing special gene therapy study sections, as clinicians had urged. "Future gene therapy research should compete with other forms of biomedical research for funding under stringent peer review," the panel reported. Meredith Wadman 